\title{
Antioxidants, anticollagenase and antielastase potentials of ethanolic extract of ripe sesoot (Garcinia picrorrhiza Miq.) fruit as antiaging
}

Sri Utami ${ }^{1 *}$, Qomariyah Romadhiyani Sachrowardi ${ }^{1}$, Ndaru Andri Damayanti $^{1}$, Arroyan Wardhana ${ }^{1}$, Irfan Syarif $^{1}$, Said Nafik ${ }^{2}$, Betharie Cendera Arrahmani ${ }^{3}$, Hanna Sari Widya Kusuma ${ }^{4}$, Wahyu Widowati ${ }^{5}$

\author{
${ }^{1}$ Faculty of Medicine, YARSI University, Central Jakarta, Indonesia \\ ${ }^{2}$ Directorate General of Intellectual Property, Ministry of Law and Human Rights, Republic of Indonesia, South Jakarta, Indonesia \\ ${ }^{3}$ Faculty of Business and Engineering, University of Applied Sciences Würzburg-Schweinfurt, Schweinfurt, Germany \\ ${ }^{4}$ Aretha Medika Utama, Biomolecular and Biomedical Research Center, Bandung, Indonesia \\ ${ }^{5}$ Faculty of Medicine, Maranatha Christian University, Bandung, Indonesia
}

\section{AR T I C L E I N F O}

\section{Article Type:}

Original Article

\section{Article History:}

Received: 26 September 2017

Accepted: 10 January 2018

\section{Keywords:}

GpKar

Antioxidant

Anticollagenase

Antielastase

Antiaging

\begin{abstract}
A B S T R A C T
Introduction: Nitric oxide (NO) is a free radical that belongs to reactive nitrogen species (RNS). The excess amount of NO in body generates physical changing on skin as a consequence of alteration in connective tissue through formation of lipid peroxides, cell content, and enzymes. These free radicals induce damage to extracellular matrix (ECM) and are responsible in reducing skin elasticity. Antioxidants possess significant role in delaying aging process by scavenging free radicals and preventing collagenase and elastase enzymes activities. This study aimed to evaluate

antioxidants, anticollagenase and antielastase potentials of ethanolic extract of ripe sesoot (Garcinia picrorrhiza Miq.) fruit (GpKar) as antiaging remedy.

Methods: Antioxidant activity was performed by NO scavenging activity assay, while anti-aging activity was performed through inhibitory effects of collagenase and elastase activities.

Results: In antioxidant activity, GpKar had lower NO scavenging activity $\left(\mathrm{IC}_{50}=1530.34 \mu \mathrm{g} /\right.$ $\mathrm{mL}$ ) compared to xanthone ( $\mathrm{IC}_{50}=85.40 \mu \mathrm{g} / \mathrm{mL}$ ). In collagenase inhibitory activity, GpKar also had lower inhibition collagenase activity $\left(\mathrm{IC}_{50}=1169.31 \mu \mathrm{g} / \mathrm{mL}\right)$ compared to xanthone $\left(\mathrm{IC}_{50}=\right.$ $286.32 \mu \mathrm{g} / \mathrm{mL}$ ). In elastase inhibitory activity, GpKar had lower inhibition elastase activity $\left(\mathrm{IC}_{50}=152.93 \mu \mathrm{g} / \mathrm{mL}\right)$ compared to xanthone $\left(\mathrm{IC}_{50}=21.26 \mu \mathrm{g} / \mathrm{mL}\right)$.

Conclusion: In summary, GpKar and its compounds possess antioxidant, anticollagenase, and antielastase activities for antiaging, and might be beneficial in these subjects.
\end{abstract}

Implication for health policy/practice/research/medical education:

Extract of G. picrorrhiza has potential to increase antioxidant, anticollagenase, and antielastase activities. Therefore, more investigations need for identification of the active compounds in G. picrorrhiza extract involved in antioxidant and antiaging activities.

Please cite this paper as: Utami S, Sachrowardi QR, Damayanti NA, Wardhana A, Syarif I, Nafik S, et al. Antioxidants, anticollagenase and antielastase potentials of ethanolic extract of ripe sesoot (Garcinia picrorrhiza Miq.) fruit as antiaging. J Herbmed Pharmacol. 2018;7(2):88-93. doi: 10.15171/jhp.2018.15

\section{Introduction}

Skin aging process is divided into two categories i.e. intrinsic aging and extrinsic aging $(1,2)$. Intrinsic aging is naturally caused by the alteration of skin elasticity as time goes by, whereas extrinsic aging generally is caused by accumulation of free radicals $(1,3)$. Nitric oxide (NO) is a free radical belonging to reactive nitrogen species
(RNS). NO is produced essentially as bio-regulatory molecule in several physiological processes such as neural signal transmission, immune response, vasodilatation, and blood pressure regulation. On certain conditions, the concentration of $\mathrm{NO}$ can be increased as a result of photo radiation or chemical exposures $(4,5)$.

In addition, the excessive NO in body may result in premature 
aging. The excessive NO leads to structural changes of cells and stimulates matrix metalloproteinases (MMPs) enzymes such as collagenase and elastase that may induce collagen and elastin loss (6-8). Collagenase is an enzyme that plays an important role in degradation of collagen. Collagen is the main component with percentage of $70 \%$ $80 \%$ of the total skin weight. The increasing degradation of collagen is significant in aging (9).

Aging can be prevented by scavenging free radicals. The excessive free radicals like NO can be reduced by escalating antioxidant intake through food or supplements. Furthermore, the other way to retard aging is inhibiting collagenase and elastase activities. As collagenase and elastase increase significantly with age, inhibiting their activities may retard skin aging without interfering their abilities to breakdown damaged skin components. In other words, the use of inhibiting agents helps restore the balance that the skin possessed when it was younger. Nowadays, the use of natural substances to prevent premature aging is more preferable in food, cosmetic, and therapeutic industry. These would be promising alternatives for synthetic antioxidants in respect of low cost, high compatibility with dietary intake and low harmful effects inside the human body. Many compounds in plants have been identified as free radical or active oxygen scavengers (10). It has been investigated that Garcinia picrorrhiza fruit contains secondary metabolites that act as antioxidant such as xanthone, biflavonoidsa, and benzophenons and their derivatives. Based on a primary research, fruit extract of G. picrorrhiza contains camboginol or garcinol, a derivative of benzophenones. In the present study, NO scavenging activities of GpKar and its compounds as well as their inhibitory activities on collagenase and elastase were evaluated.

\section{Materials and Methods}

Preparation of GpKar

Sesoot fruits were collected from Bogor Botanical Garden, Bogor, West Java. The plant was authenticated by herbarium staff of Bogor Botanical Garden. Sesoot fruits were mashed $(500 \mathrm{~g})$ and extracted using ethanol $70 \%$ by maceration method. Every 24 hours the ethanol was filtered and the wastes were re-macerated in triplicate. The ethanol filtrate was collected and condensed in $50^{\circ} \mathrm{C}$ using rotary evaporator (Hitachi) to obtain GpKar. The extract in paste form was stored at $-20^{\circ} \mathrm{C}$ and used for the assay. Standard compound used in this study was xanthone (Sigma X0626, USA) (11,12).

\section{Nitric oxygen scavenging activity assay}

Sodium nitroprusside is soluble in aqueous solution at physiological $\mathrm{pH}$ of 7.2 producing NO. NO reacts with oxygen to produce stable products (nitrate and nitrite) under aerobic conditions. Scavengers of NO compete with oxygen leading to reduced production on nitrite ions.
Griess reagent was used in NO assay (13).

In this study the NO scavenging activity was estimated using Griess Illosvoy reaction based on the method that was performed by Parul et al with minor modifications (14). Sodium nitroprusside (10 mM) (Merck 106541, Germany) in phosphate buffered saline (PBS) (Gibco 1740576, Canada) was mixed with different concentrations of GpKar and xanthone $(20.83-666.67 \mu \mathrm{g} / \mathrm{mL} ; \mu \mathrm{M})$. The mixtures were incubated for 2 hours in $25^{\circ} \mathrm{C}$. After the incubation period, Griess reagent ( $1 \%$ sulfanilamide [Merck 111799, Germany], 2\% $\mathrm{H}_{3} \mathrm{PO}_{4}$ [Merck 100573, Germany] and $0.1 \% \mathrm{~N}$-(1-napththyl) ethylenediamine dihydrochloride) (Sigma 222488, USA) were added. The absorbance of the chromophore that was formed during diazotization of the nitrite with sulfanilamide and subsequent coupling with Naphthylethylenediamine dihydrochloride was read at $546 \mathrm{~nm}$ with microplate reader (Thermo Scientific Multiscan GO). The same reaction mixture without the extract yet equivalent in amount of ethanol served as the control.

Collagenase inhibitory activity assay as antiaging potential Inhibition of collagenase activity was measured based on the method that was elaborated by Sigma Aldrich and Thring et al with some modifications. The assay was performed by dissolving $10 \mu \mathrm{L}$ collagenase from Clostridium histolyticum (Sigma C8051, USA) (0.01 U/ $\mathrm{mL}$ in cold distilled water), $60 \mu \mathrm{L}$ buffer Tricine $(50 \mathrm{mM}$, $\mathrm{pH}$ 7.5, contains $10 \mathrm{mM} \mathrm{CaCl}_{2}$ and $400 \mathrm{mM} \mathrm{NaCl}$ ), 30 $\mu \mathrm{L}$ sample $(0-250 \mu \mathrm{g} / \mathrm{mL}$ in DMSO). The mixtures were incubated for 20 minutes at $37^{\circ} \mathrm{C}$. After incubation time, $20 \mu \mathrm{L}$ substrate $\mathrm{N}$-[3-(2-Furyl)acryloyl]-leu-gly-Pro-Ala (Sigma F5135, USA) (1 mM in buffer Tricine) was added. Absorbance at $335 \mathrm{~nm}$ was measured immediately after adding the substrate $(11,15,16)$.

$\%$ Collagenase inhibition $=(1-\mathrm{B} / \mathrm{A}) \times 100 \%$

A $=$ Sample absorbance

$\mathrm{B}=$ Control absorbance

\section{Elastase inhibitory activity assay}

Elastase inhibitory activity was measured by modified method of Sigma Aldrich and Thring et al with some modifications by Widowati et al $(11,15)$. A mixture of 10 $\mu \mathrm{L}$ of various levels of samples $(4.17-133.33 \mu \mathrm{g} / \mathrm{mL}), 5 \mu \mathrm{L}$ elastase from porcine pancreas (Sigma 45124, USA) (0.5 $\mathrm{mU} / \mathrm{mL}$ in the cold distilled water) and $125 \mu \mathrm{L}$ Tris buffer was pre-incubated for 15 minutes at $25^{\circ} \mathrm{C}$. Mix solution was added N-Sucanyl-Ala-Ala-Ala-p-Nitroanilide substrate [Sigma 54760, USA] and then incubated for 15 minutes at $25^{\circ} \mathrm{C}$. Absorbance was measured immediately after incubation time with $410 \mathrm{~nm}$ wavelength.

$\%$ Elastase inhibition $=(1-\mathrm{B} / \mathrm{A}) \times 100 \%$

A = Sample absorbance

$\mathrm{B}=$ Control absorbance 


\section{Results}

The effect of GpKar on nitric oxide scavenging activity Inhibition potentials of nitrite formation by GpKar and the standard antioxidant xanthone were calculated relative to the control. Inhibition data (percentage inhibition) were linearized against the concentration of each extract and standard antioxidant. $\mathrm{IC}_{50}$ which is an inhibitory concentration of each extract required to reduce $50 \%$ of the NO formation was determined (14).

Figure 1 shows that the NO scavenging activity was concentration dependent. At the highest concentration $(666.67 \mu \mathrm{g} / \mathrm{mL}) \mathrm{NO}$ scavenging activity of GpKar $(20.26$ $\pm 0.47 \%)$ was higher than xanthone $(63.38 \pm 0.12 \%)$. Furthermore, $\mathrm{IC}_{50}$ value of GpKar $(1530.34 \mu \mathrm{g} / \mathrm{mL})$ was higher than xanthone $(85.40 \mu \mathrm{g} / \mathrm{mL})$ (Table 1). These results indicate that GpKar has lower NO scavenging activity compared to xanthone.

The effect of GpKar on collagenase inhibitory activity A spectrophotometric method was performed to find out collagenase inhibitory activity. The collagenase inhibitory activity of GpKar and xanthone can be seen in Figure 2 and Table 2. Figure 2 shows that collagenase inhibitory activities of GpKar and xanthone are concentrationdependent. At the highest concentration $(2500 \mu \mathrm{g} / \mathrm{mL})$ collagenase inhibition activity of GpKar $(68.08 \pm 4.18 \%)$ was lower than xanthone $(68.91 \pm 1.72 \%)$. Furthermore, $\mathrm{IC}_{50}$ value of $\mathrm{GpKar}(1169.31 \mu \mathrm{g} / \mathrm{mL})$ was higher than xanthone $(286.32 \mu \mathrm{g} / \mathrm{mL}$ ) (Table 2$)$. These results indicate

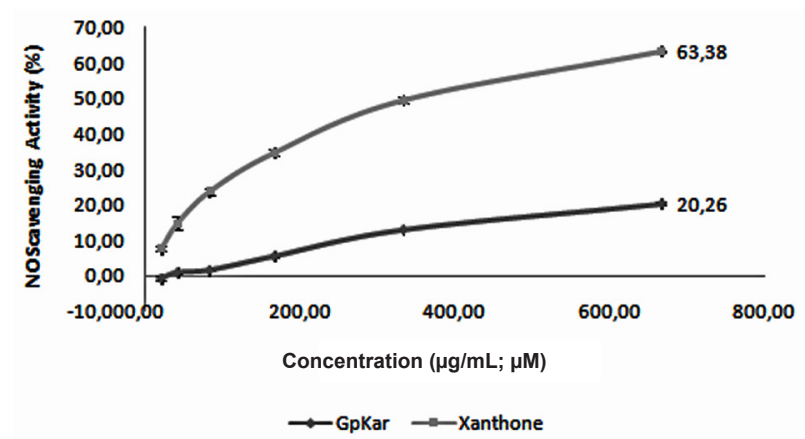

Figure 1. Nitric Oxide (NO) scavenging activity of GpKar and xanthone.

${ }^{*}$ GpKar and xanthone were diluted using DMSO to reach the final concentration of $20.83 ; 41.67 ; 83.33 ; 166.67 ; 333.33 ; 666.67$ ( $\mu \mathrm{g} /$ $\mathrm{mL} ; \mu \mathrm{M})$.

Table 1. IC $\mathrm{C}_{50}$ values of nitric oxide scavenging activities by GpKar and xanthone

\begin{tabular}{|c|c|c|c|c|}
\hline Samples & Equation & $r^{2}$ & $\mathrm{IC}_{50}(\mu \mathrm{M})$ & $\mathrm{IC}_{50}(\mu \mathrm{g} / \mathrm{mL})$ \\
\hline GpKar & $y=0.03 x-0.51$ & 0.97 & - & 1530.34 \\
\hline Xanthone & $y=0.08 x+14.48$ & 0.90 & 435.28 & 85.40 \\
\hline $\begin{array}{l}\text { *GpKar= G. } \\
\text { concentrati } \\
\text { of the samp } \\
\text { presented i }\end{array}$ & $\begin{array}{l}\text { rorrhiza extracts } \\
\text { inear equations, } \\
\text { were calculated. I } \\
1 \text { and } \mu \mathrm{g} / \mathrm{mL} \text {. }\end{array}$ & $\begin{array}{l}\mathrm{C} 50= \\
\text { effici } \\
0 \text { of }\end{array}$ & half $\mathrm{m}$ & $\begin{array}{l}\text { tal inhibitory } \\
\text { (r2) and IC50 } \\
\text { anthone was }\end{array}$ \\
\hline
\end{tabular}

that GpKar has lower collagenase inhibitory activity compared to xanthone.

The effect of GpKar on elastase inhibitory activity The percentage of elastase inhibitory activities of GpKar and xanthone can be seen in Figure 3. Figure 3 shows that the elastase inhibitory activities of GpKar and xanthone are concentration-dependent. At the highest concentration $(133.33 \mu \mathrm{g} / \mathrm{mL})$, the elastase inhibitory activity of GpKar $(40.37 \pm 3.11 \%)$ was lower than xanthone $(59.55 \pm 0.48 \%)$. Furthermore, $\mathrm{IC}_{50}$ value of GpKar $(152.93 \mu \mathrm{g} / \mathrm{mL})$ was higher than xanthone $(21.26 \mu \mathrm{g} / \mathrm{mL})$ (Table 3$)$. These results indicate that GpKar has lower elastase inhibitory activity compared to xanthone.

\section{Discussion}

The natural substances from plants have been widely used for treating aging. It has been investigated that the investigated plant contains active antioxidants that are related to its phytochemical compounds $(17,18)$. In several studies, some plants have shown the ability to reduce free radicals having anti-aging potential through their components such as polyphenols from blackberry, curcumin from C. longa (19), procyanidins from $V$. vinifera (20) and garcinol from G. indica (21).

Sesoot belongs to genus of Garcinia. Recent studies have shown that sesoot contains high levels of xanthone, bioflavonoids, and prenylated benzophenones. Previous studies have shown that the extract of sesoot fruit

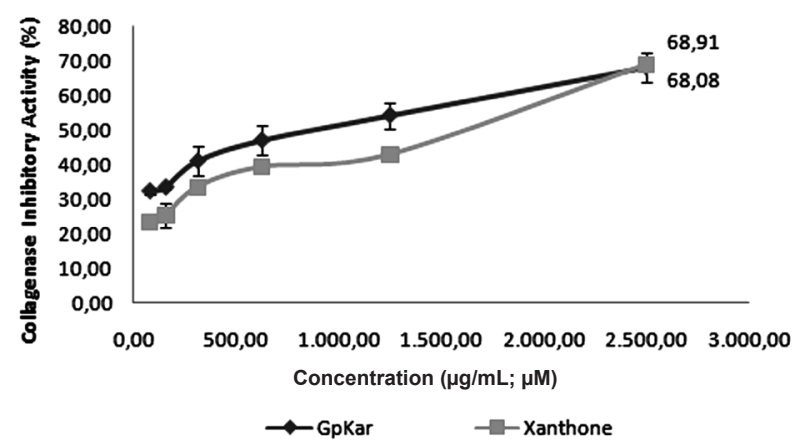

Figure 2. Collagenase inhibitory activity of GpKar and Xanthone. *GpKar and Xanthone were diluted using DMSO to reach the final concentration of $78.125 ; 156.25 ; 312.5 ; 625.00 ; 1250.00 ; 2500.00$ $(\mu \mathrm{g} / \mathrm{mL} ; \mu \mathrm{M})$.

Table 2. $I C_{50}$ values of of collagenase inhibitory activities by GpKar and xanthone

\begin{tabular}{lcccc}
\hline Samples & Equation & $\mathbf{r}^{2}$ & $\mathbf{I C}_{50}(\boldsymbol{\mu M})$ & $\mathbf{I C}_{50}(\boldsymbol{\mu g} / \mathrm{mL})$ \\
\hline GpKar & $\mathrm{y}=0.01 \mathrm{x}+34.28$ & 0.92 & - & 1169.31 \\
Xanthone & $\mathrm{y}=0.02 \mathrm{x}+24.69$ & 0.96 & 1459.35 & 286.32 \\
\hline
\end{tabular}

*GpKar= G. picrorrhiza extracts, IC50 $=$ The half maximal inhibitory concentration. Linear equations, coefficient of regression ( $r 2$ ) and IC50 of the samples were calculated. IC50 of GpKar in $\mu \mathrm{g} / \mathrm{mL}$ xanthone was presented in $\mu \mathrm{M}$ and $\mu \mathrm{g} / \mathrm{mL}$. 


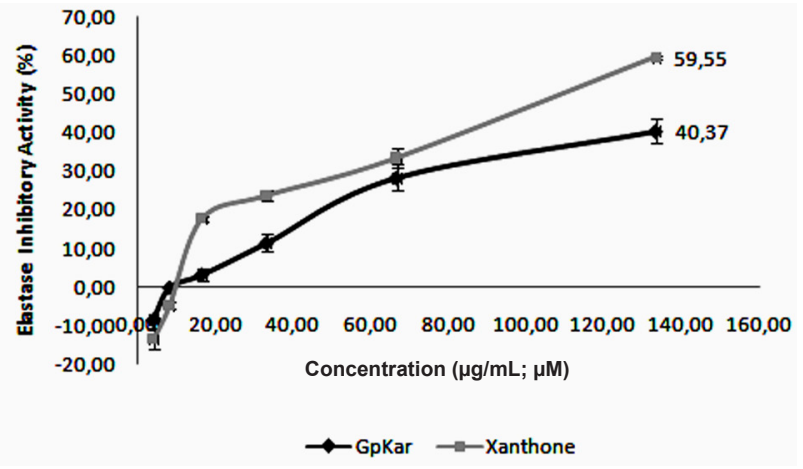

Figure 3. Elastase inhibitory activity of GpKar and Xanthone. *GpKar and xanthone were diluted using DMSO to reach the final concentration of 4.17 ; $8.33 ; 16.67 ; 33.33 ; 66.67 ; 133.33(\mu \mathrm{g} / \mathrm{mL} ; \mu \mathrm{M})$.

Table 3. $I C_{50}$ values of of elastase inhibitory activities by GpKar and xanthone

\begin{tabular}{lcccc}
\hline Samples & Equation & $\mathbf{r}^{2}$ & IC $_{50}(\mu \mathrm{M})$ & $\mathrm{IC}_{50}(\boldsymbol{\mu g} / \mathrm{mL})$ \\
\hline GpKar & $\mathrm{y}=0.33 \mathrm{x}-0.25$ & 0.94 & - & 152.93 \\
Xanthone & $\mathrm{y}=0.36 \mathrm{x}+11.28$ & 0.99 & 108.38 & 21.26 \\
\hline
\end{tabular}

*GpKar $=$ G. picrorrhiza extracts, IC50 $=$ The half maximal inhibitory concentration. Linear equations, coefficient of regression ( $r 2$ ) and IC50 of the samples were calculated. IC50 of GpKar in $\mu \mathrm{g} / \mathrm{mL}$ xanthone was presented in $\mu \mathrm{M}$ and $\mu \mathrm{g} / \mathrm{mL}$.

has camboginol or garcinol compound, a derivate of benzophenones that has various therapeutic activities. Xanthone compounds in sesoot are oxygenated xanthones and prenylated ones. Due to the xanthone itself that has phenolic functional group on linear tri-cyclic ring, xanthone has a wide range of biological activities such as antioxidant property (22).

In this study, GpKar was tested to find out its potential in NO scavenging potential, as anticollagenase and antielastase agent. In NO scavenging assay, GpKar has higher $\mathrm{IC}_{50}$ value compared to xanthone. It means that GpKar has lower NO scavenging activity than xanthone does. Even though GpKar has lower $\mathrm{IC}_{50}$ than xanthone but GpKar still indicates antioxidant potential. The Garcinia contains camboginol that structurally is similar to a well-known antioxidant, curcumin, which contains both phenolic hydroxyl groups and $\beta$-diketone moiety. Several studies have demonstrated that garcinol exhibits significantly the antioxidative property and possesses inhibitory activity on lipid peroxidation $(23,24)$.

$\mathrm{NO}$ is an important chemical mediator generated by endothelial cells, macrophages and neurons which is involved in regulation of physiological processes (14). $\mathrm{NO}$ is generated in biological tissues by a specific NO synthase, which metabolizes arginine to citraline with the formation of NO via five electrons of oxidative reaction (25). Nevertheless, the excess amount of NO in body may result in aging acceleration or even degenerative chronic ailments (6). In aging-acceleration process, NO does not interact directly with DNA or proteins. However, under aerobic conditions, $\mathrm{NO}$ is very unstable and reacts with oxygen to produce $\mathrm{NO}_{2}, \mathrm{~N}_{2} \mathrm{O}_{4}, \mathrm{~N}_{3} \mathrm{O}_{4}$ the stable products of nitrate and nitrite and peroxynitrite when reacted with superoxide. These progenitors are highly genotoxic. Besides, NO may affect enzymatic activities that lead to mutagenesis (26). NO is responsible for altering the structural and functional behavior of many cellular components. Antioxidants have the ability to reduce NO by donating their electron. This may be due to the antioxidant principles in the extract, which compete with oxygen to react with $\mathrm{NO}$, thereby inhibiting the production of nitrite (14).

Skin aging is a natural process that occurs in organisms with characteristic of losing skin elasticity implicated in formation of wrinkle, uneven pigmentation, brown spots, laxity and leathery appearance (11). Though aging will occur naturally but at some conditions it can be accelerated by some factors like free radicals. Aging can be characterized by its physical and psychosocial changing. Physical changing in visual can lessen skin-elasticity, causing wrinkle, uneven pigmentation, brown spots, laxity and leathery appearance (16). The excess of free radicals in body may overturn natural cellular antioxidant defense and lead to oxidation and further contributing to cellular functional impairment (27).

During aging process, there is also imbalance between collagen production and degradation. Collagen production decreases whereas level of collagenase increases. Exact mechanism of wrinkles formation is still unknown but it has been observed that free radicals cause enhancement in the expression of MMPs which is collagenase and elastase, which in turn causes repetitive breakdown of collagen and elastine (28). However, undesirable aging can also be retarded by scavenging free radical with antioxidant and inhibiting collagenase and elastase activitie. Other than that, in collagenase and elastase inhibition activities, GpKar has lower inhibitory activity compared with xanthone. In collagenase inhibitory activity assay, the $\mathrm{IC}_{50}$ value of collagenase inhibitory activity of GpKar was higher than xanthone (Table 2) and in elastase inhibitory activity $\mathrm{IC}_{50}$ value of GpKar was higher than Xanthone (Table 3). These results indicate that GpKar has lower collagenase and elastase inhibitory activity compared to xanthone. Collagen and elastin are the main components of skin that possess important role in maintaining skin structure. Collagenase and elastase enzymes cause repetitive collagen breakdown and are responsible for structural defect in dermis and wrinkle development (29). Collagenase and elastase contribute to production and degradation of collagen and elastin (30).

\section{Conclusion}

In summary, GpKar and its compounds possess antioxidant and antiaging activities and might be used to prevent aging. However, xanthone has higher antioxidant 
power through NO scavenging activity and has higher collagenase and elastase inhibitory activities than GpKar.

\section{Acknowledgements}

This research was funded by YARSI Foundation, Jakarta, Indonesia and supported by Biomolecular and Biomedical Research Center, Aretha Medika Utama, Bandung, Indonesia. We thank to Ervi Afifah, Seila Arumwardana, Dwi Davidson Rihibiha, Hayatun Nufus, Annisa Amalia, and Yuko Arinta from Biomolecular and Biomedical Research Center, Aretha Medika Utama for their technical support.

\section{Authors' contributions}

Author contribution of this study in literature search were QRS, NAD, AW, and IS. SU, QRS, NAD, AW, and IS developed the theory and designed the study. The data collection and data analysis were through SU, HSWK, and WW. The data interpretation and writing were through SU, BCA, SN, HSWK and WW.

\section{Conflict of interests}

All contributing authors declare no conflicts of interest.

\section{Ethical considerations}

All procedures were approved by the ethics committee of YARSI University $(0415 / \mathrm{K} 3 / \mathrm{KM} / 2017)$ and considered in all aspects of the work.

\section{Funding/Support}

This research was financially supported by YARSI University (Research grant 2016) and also Aretha Medika Utama Biomolecular and Biomedical Research Center, Bandung, Indonesia supported with methodology and laboratory facilities.

\section{References}

1. Longo VD, Finch CE. Evolutionary medicine: from dwarf model systems to healthy centenarians? Science. 2003;299(5611):1342-46. doi: 10.1126/science.1077991.

2. Bartke A. Long-lived Klotho mice: new insights into the roles of IGF-1 and insulin in aging. Trends Endocrinol Metab. 2006;17(2):33-35. doi: 10.1016/j.tem.2006.01.002.

3. Kirkwood TB. Understanding the odd science of aging. Cell. 2005;120(4):437-47. doi: 10.1016/j.cell.2005.01.027.

4. Hickok JR, Thomas DD. Nitric oxide and cancer therapy: the emperor has NO clothes. Curr Pharm Des. 2010;16(4):38191. doi: 10.2174/138161210790232149.

5. Kammeyer A, Luiten RM. Oxidation events and skin aging. Ageing Res Rev. 2015;21:16-29. doi: 10.1016/j. arr.2015.01.001.

6. Jagetia GC, Baliga MS. The evaluation of nitric oxide scavenging activity of certain Indian medicinal plants in vitro: a preliminary study. J Med Food. 2004;7(3):343-48. doi: 10.1089/jmf.2004.7.343.

7. Shin R, Berg RH, Schachtman DP. Reactive oxygen species and root hairs in Arabidopsis root response to nitrogen, phosphorus and potassium deficiency. Plant Cell Physiol. 2005;46(8):1350-57. doi: 10.1093/pcp/pci145.

8. Obayashi K, Akamatsu H, Okano Y, Matsunaga K, Masaki H. Exogenous nitric oxide enhances the synthesis of type I collagen and heat shock protein 47 by normal human dermal fibroblasts. J Dermatol Sci. 2006;41(2):121-26. doi: 10.1016/j.jdermsci.2005.08.004.

9. Demina NS, Lysenko SV. [Collagenolytic enzymes synthesized by microorganisms]. Mikrobiologiia. 1996;65(3):293-04.

10. Lobo V, Patil A, Phatak A, Chandra N. Free radicals, antioxidants and functional foods: Impact on human health. Pharmacogn Rev. 2010;4(8):118-26. doi: 10.4103/09737847.70902.

11. Widowati W, Fauziah N, Herdiman H, Afni M, Afifah E, Kusuma HSW, et al. Antioxidant and anti aging assays of Oryza sativa extracts, vanillin and coumaric acid. J Nat Remed. 2016;16(3):88-99. doi: 10.18311/ jnr/2016/7220.

12. Widowati W, Wijaya L, Wargasetia TL, Bachtiar I, Yellianty Y, Laksmitawati DR. Antioxidant, anticancer, and apoptosis inducing effects of piper extracts in hela cells. J Exp Integr Med. 2013;3(3):225-30. doi: 10.5455/jeim.160513.or.074.

13. Amudha M, Rani S. Evaluation of in vitro antioxidant potential of Cordia retusa. Indian J Pharm Sci. 2016;78(1):8086. doi: 10.4103/0250-474x.180253.

14. Parul R, Saha P, Kumar Kundu S. In vitro nitric oxide scavenging activity of methanol extracts of three Bangladeshi medicinal plants. Pharm Innov. 2012;1(12):8388.

15. Thring TS, Hili P, Naughton DP. Anti-collagenase, antielastase and anti-oxidant activities of extracts from 21 plants. BMC Complement Altern Med. 2009;9:27. doi: 10.1186/1472-6882-9-27.

16. Widowati W, Rani AP, Hamzah RA, Arumwardana S, Afifah E, Kusuma HSW, et al. Antioxidant and antiaging assays of Hibiscus sabdariffa extract and its compounds. Nat Prod Sci. 2017;23(3):192-00. doi: 10.20307/nps.2017.23.3.192.

17. Allaith AAA. Antioxidant activity of Bahraini date palm (Phoenix dactylifera L.) fruit of various cultivars. Int J Food Sci Technol. 2008;43(6):1033-40. doi: 10.1111/j.13652621.2007.01558.x.

18. Ismail A, Marjan ZM, Foong CW. Total antioxidant activity and phenolic content in selected vegetables. Food Chem. 2004;87(4):581-86. doi: 10.1016/j.foodchem.2004.01.010.

19. Chainani-Wu N. Safety and anti-inflammatory activity of curcumin: a component of tumeric (Curcuma longa). J Altern Complement Med. 2003;9(1):161-68. doi: $10.1089 / 107555303321223035$.

20. Maffei Facino R, Carini M, Aldini G, Bombardelli E, Morazzoni P, Morelli R. Free radicals scavenging action and anti-enzyme activities of procyanidines from Vitis vinifera. A mechanism for their capillary protective action. Arzneimittelforschung. 1994;44(5):592-01.

21. Yu SY, Liao CH, Chien MH, Tsai TY, Lin JK, Weng MS. Induction ofp21(Waf1/Cip1) bygarcinolvia downregulation of p38-MAPK signaling in p53-independent H1299 lung cancer. J Agric Food Chem. 2014;62(9):2085-95. doi: $10.1021 /$ jf4037722.

22. Sordat-Diserens I, Hamburger M, Rogers C, Hostettmannt K. Dimeric xanthones from Garcinia livingstonei. 
Phytochem. 1992;31(10):3589-93. doi: 10.1016/00319422(92)83732-E.

23. Krishnamurthy N, Lewis YS, Ravindranath B. On the structures of garcinol, isogarcinol and camboginol. Tetrahedron Lett. 1981;22(8):793-6. doi: 10.1016/00404039(81)80154-2.

24. Liao CH, Ho CT, Lin JK. Effects of garcinol on free radical generation and $\mathrm{NO}$ production in embryonic rat cortical neurons and astrocytes. Biochem Biophys Res Commun. 2005;329(4):1306-14. doi: 10.1016/j.bbrc.2005.02.110.

25. Ross R. The pathogenesis of atherosclerosis: a perspective for the 1990s. Nature. 1993;362(6423):801-09. doi: $10.1038 / 362801 \mathrm{a} 0$.

26. Baliga MS, Jagetia GC, Rao SK, Babu K. Evaluation of nitric oxide scavenging activity of certain spices in vitro: a preliminary study. Nahrung. 2003;47(4):261-64. doi: 10.1002/food.200390061.

27. Fusco D, Colloca G, Lo Monaco MR, Cesari M. Effects of antioxidant supplementation on the aging process. Clin Interv Aging. 2007;2(3):377-87. PMID: 18044188

28. Hooda R. Antiwrinkle herbal drugs-an update. J Pharmacog Phytochem.2015;4(4):277-81.

29. Shaheda S, Duraivel S, Niharika R, Anusha P, Qudusiya SM. A review on natural bioactive compounds as potential antiwrinkle agents. World J Pharm Pharm Sci. 2014;3(3):52844.

30. Mukherjee PK, Maity N, Nema NK, Sarkar BK. Bioactive compounds from natural resources against skin aging. Phytomed. 2011;19(1):64-73. doi: 10.1016/j. phymed.2011.10.003. 